\title{
Desulfovibrio frigidus sp. nov. and Desulfovibrio ferrireducens sp. nov., psychrotolerant bacteria isolated from Arctic fjord sediments (Svalbard) with the ability to reduce $\mathrm{Fe}(\mathrm{III})$
}

\author{
Verona Vandieken, ${ }^{1}$ Christian Knoblauch ${ }^{2}$ and Bo Barker Jørgensen ${ }^{1}$ \\ ${ }^{1}$ Max-Planck-Institute for Marine Microbiology, Celsiusstr. 1, 28359 Bremen, Germany \\ ${ }^{2}$ University of Hamburg, Institute of Soil Science, Allende-Platz 2, 20146 Hamburg, Germany
}

Verona Vandieken

vvandiek@mpi-bremen.de

\begin{abstract}
Strains $18^{\top}, 61^{\top}$ and 77 were isolated from two permanently cold fjord sediments on the west coast of Svalbard. The three psychrotolerant strains, with temperature optima at $20-23^{\circ} \mathrm{C}$, were able to grow at the freezing point of sea water, $-2{ }^{\circ} \mathrm{C}$. The strains oxidized important fermentation products such as hydrogen, formate and lactate with sulfate as the electron acceptor. Sulfate could be replaced by sulfite, thiosulfate or elemental sulfur. Poorly crystalline and soluble Fe(III) compounds were reduced in sulfate-free medium, but no growth occurred under these conditions. In the absence of electron acceptors, fermentative growth was possible. The $\mathrm{pH}$ optimum for the strains was around $7 \cdot 1$. The DNA G $+C$ contents were $43 \cdot 3$ and $42 \cdot 0$ mol\% for strains $18^{\top}$ and $61^{\top}$, respectively. Strains $18^{\top}, 61^{\top}$ and 77 were most closely related to Desulfovibrio hydrothermalis (95.0-95.7\% 16S rRNA gene sequence similarity). Strains $18^{\top}$ and 77 , exhibiting $99.9 \%$ sequence similarity, represent a novel species for which the name Desulfovibrio frigidus sp. nov. is proposed. The type strain is strain $18^{\top}\left(=\mathrm{DSM} 17176^{\top}=\mathrm{JCM} 12924^{\top}\right)$. Strain $61^{\top}$ was closely related to strains $18^{\top}$ and 77 (97.6 and $97.5 \% 16$ S rRNA gene sequence similarity), but on the basis of DNA-DNA hybridization strain $61^{\top}$ represents a novel species for which the name Desulfovibrio ferrireducens sp. nov. is proposed. The type strain is strain $61^{\top}$ $\left(=\mathrm{DSM} 16995^{\top}=\mathrm{JCM} 12925^{\top}\right)$.
\end{abstract}

Dissimilatory sulfate reduction is the most important anaerobic mineralization pathway in many temperate and permanently cold marine sediments (e.g. Jørgensen, 1982; Canfield et al., 1993; Thamdrup \& Canfield, 1996; Rysgaard et al., 1998; Kostka et al., 1999; Glud et al., 2000). Most sulfate-reducing bacteria are phylogenetically placed within the Deltaproteobacteria, including the genus Desulfovibrio, which comprises 42 described species. A special characteristic of some Desulfovibrio strains is the ability to reduce $\mathrm{Fe}(\mathrm{III})$ compounds without gaining energy for growth (Coleman et al., 1993; Lovley et al., 1993; Li et al., 2004). Here, we report the isolation of three novel psychrotolerant Desulfovibrio-related strains with the ability to reduce $\mathrm{Fe}(\mathrm{III})$.

Strain $61^{\mathrm{T}}$ was isolated from an enrichment culture of artificial sea-water medium (Widdel \& Bak, 1992) with

Published online ahead of print on 18 November 2005 as DOI 10.1099/ijs.0.64057-0.

The GenBank/EMBL/DDBJ accession numbers for the 16S rRNA gene sequences of Desulfovibrio frigidus strains $18^{\top}$ and 77 are D0148943 and DQ148945, and that for Desulfovibrio ferrireducens strain $61^{\top}$ is DQ148944. approximately $30 \mathrm{mM}$ poorly crystalline iron oxide, $0 \cdot 4 \mathrm{mM} \mathrm{MgSO}{ }_{4} \cdot 7 \mathrm{H}_{2} \mathrm{O}$ and $20 \mathrm{mM}$ lactate at $10^{\circ} \mathrm{C}$, which was inoculated with surface sediment of Tempelfjorden, Station $\mathrm{CD}\left(78^{\circ} 25 \cdot 267^{\prime} \mathrm{N} 17^{\circ} 08 \cdot 277^{\prime} \mathrm{E}\right.$; bottom water temperature $2 \cdot 8^{\circ} \mathrm{C}$ ). Iron oxide was replaced by ferric citrate (approx. $30 \mathrm{mM}$ ) for isolation in deep-agar dilution series. Cells of strain $61^{\mathrm{T}}$ were motile vibrios and the 16S rRNA gene sequence was $95 \cdot 7 \%$ similar to the sequence of Desulfovibrio hydrothermalis $\mathrm{AM}^{2} 3^{\mathrm{T}}$. The ability of Desulfovibrio desulfuricans to reduce $\mathrm{Fe}(\mathrm{III})$ for several consecutive transfers has been shown previously (Lovley et al., 1993); however, the authors suggested that the strains grew with $0.3 \mathrm{mM}$ sulfate in the medium and not by $\mathrm{Fe}(\mathrm{III})$ reduction. Correspondingly, we could not determine unequivocally whether strain $61^{\mathrm{T}}$ grew by $\mathrm{Fe}(\mathrm{III})$ reduction or with $0.4 \mathrm{mM}$ sulfate in the medium. Strains $18^{\mathrm{T}}$ and 77 were enriched and isolated under sulfate-reducing conditions with $28 \mathrm{mM}$ sulfate, $20 \mathrm{mM}$ lactate and $10 \mathrm{mM}$ formate at 4 and $17^{\circ} \mathrm{C}$ from sediment of Tempelfjorden, Station CC $\left(78^{\circ} 26 \cdot 039^{\prime} \mathrm{N}\right.$ $17^{\circ} 19 \cdot 722^{\prime} \mathrm{E}$; bottom water temperature $3 \cdot 1^{\circ} \mathrm{C}$ ) and Smeerenburgfjorden, Station J $\left(79^{\circ} 42 \cdot 006^{\prime} \mathrm{N} 11^{\circ} 05 \cdot 199^{\prime} \mathrm{E}\right.$; bottom water temperature $2 \cdot 3^{\circ} \mathrm{C}$ ), respectively. $16 \mathrm{~S}$ rRNA gene sequencing showed that strains $18^{\mathrm{T}}$ and 77 were closely 
related to Desulfovibrio hydrothermalis and the novel strain $61^{\mathrm{T}}$.

The general physiological characteristics of strains $18^{\mathrm{T}}, 61^{\mathrm{T}}$ and 77 were evaluated under sulfate-reducing conditions with lactate as the electron donor in a medium with a lower salt concentration (salt-water medium) (Widdel \& Bak, 1992) at their respective isolation temperature. Cultures growing with alternative substrates were transferred into fresh test medium for verification. Temperature tolerance of the strains was determined in an aluminium temperaturegradient block at 12 different temperatures between -2 and $32{ }^{\circ} \mathrm{C}$ (Sagemann et al., 1998). The salt requirement was determined in media with 12 different $\mathrm{NaCl}$ concentrations between 0.05 and $5 \%(\mathrm{w} / \mathrm{v})$ and 10 different $\mathrm{MgCl}_{2} \cdot 6 \mathrm{H}_{2} \mathrm{O}$ concentrations between 0.02 and $3.6 \%(\mathrm{w} / \mathrm{v})$. The $\mathrm{pH}$ optima of the strains were determined in media with 12 different $\mathrm{pH}$ values (in triplicate) that covered a range from pH $5 \cdot 5$ to $8 \cdot 8$. For all tests, growth was monitored spectrophotometrically (UV 1202; Shimadzu) by measuring optical density at $580 \mathrm{~nm}$.

PCR amplification of $16 \mathrm{~S}$ rRNA gene was performed with the primers $8 \mathrm{~F}$ and $1492 \mathrm{R}$, and the PCR product was amplified for sequence analysis with primers $8 \mathrm{~F}, 341 \mathrm{~F}, 518 \mathrm{~F}$, 534R, 1099F and 1492R (Buchholz-Cleven et al., 1997). Phylogenetic positions of the three novel strains were evaluated by using the ARB program (Ludwig et al., 2004) with the neighbour-joining, maximum-likelihood and maximumparsimony algorithms in combination with different sets of filters.

Strains $61^{\mathrm{T}}$ and 77 showed a vibrioid or sigmoid morphology, $2 \cdot 5-5 \cdot 5 \times 0 \cdot 5-0 \cdot 7 \mu \mathrm{m}$ in size, whereas cells of strain $18^{\mathrm{T}}$ were straight rods, $3.5-4.5 \times 0 \cdot 5-0 \cdot 7 \mu \mathrm{m}$ in size. Cells of all strains were motile by means of a single polar flagellum as indicated by electron microscopy (Fig. 1). Gram staining was negative for all strains.

Vitamins were not required for growth. The strains grew at sea-water concentrations of $\mathrm{NaCl}$ and $\mathrm{MgCl}_{2}$. $\mathrm{NaCl}$ optima were $2-3 \%$ for strains $18^{\mathrm{T}}$ and 77 and $1-2 \cdot 5 \%$ for strain $61^{\mathrm{T}}$, and strains $18^{\mathrm{T}}, 61^{\mathrm{T}}$ and 77 grew with $\mathrm{NaCl}$ concentrations of $2-3 \cdot 5,0 \cdot 7-4$ and $1 \cdot 5-4 \%$, respectively. $\mathrm{MgCl}_{2}$ optima were $0 \cdot 04-1 \cdot 9,0 \cdot 02-2 \cdot 5$ and $0.4 \%$ and $\mathrm{MgCl}_{2}$ growth ranges were from 0.02 to $2 \cdot 5$, to 3.5 and to $1.9 \%$ for strains $18^{\mathrm{T}}, 61^{\mathrm{T}}$ and 77 , respectively. The $\mathrm{pH}$ optima were $6 \cdot 9-7 \cdot 2,7 \cdot 1-7 \cdot 5$ and $7 \cdot 1$ and growth was observed at $\mathrm{pH} 6 \cdot 9-7 \cdot 5,6 \cdot 3-7 \cdot 5$ and $6 \cdot 7-7 \cdot 5$ for strains $18^{\mathrm{T}}, 61^{\mathrm{T}}$ and 77 , respectively. Common end-products of fermentation such as lactate, formate and hydrogen served as electron donors (Table 1). The strains reduced sulfate and other sulfur compounds like sulfite, thiosulfate or elemental sulfur (Table 1). Reduction of ferric citrate or poorly crystalline iron oxide in sulfate-free medium was observed in two to four consecutive transfers for all three strains. Reduction of $\mathrm{Fe}(\mathrm{III})$ became slower with every transfer and we suggest that the strains did not conserve energy for growth. The ability for $\mathrm{Fe}(\mathrm{III})$ reduction was previously described for

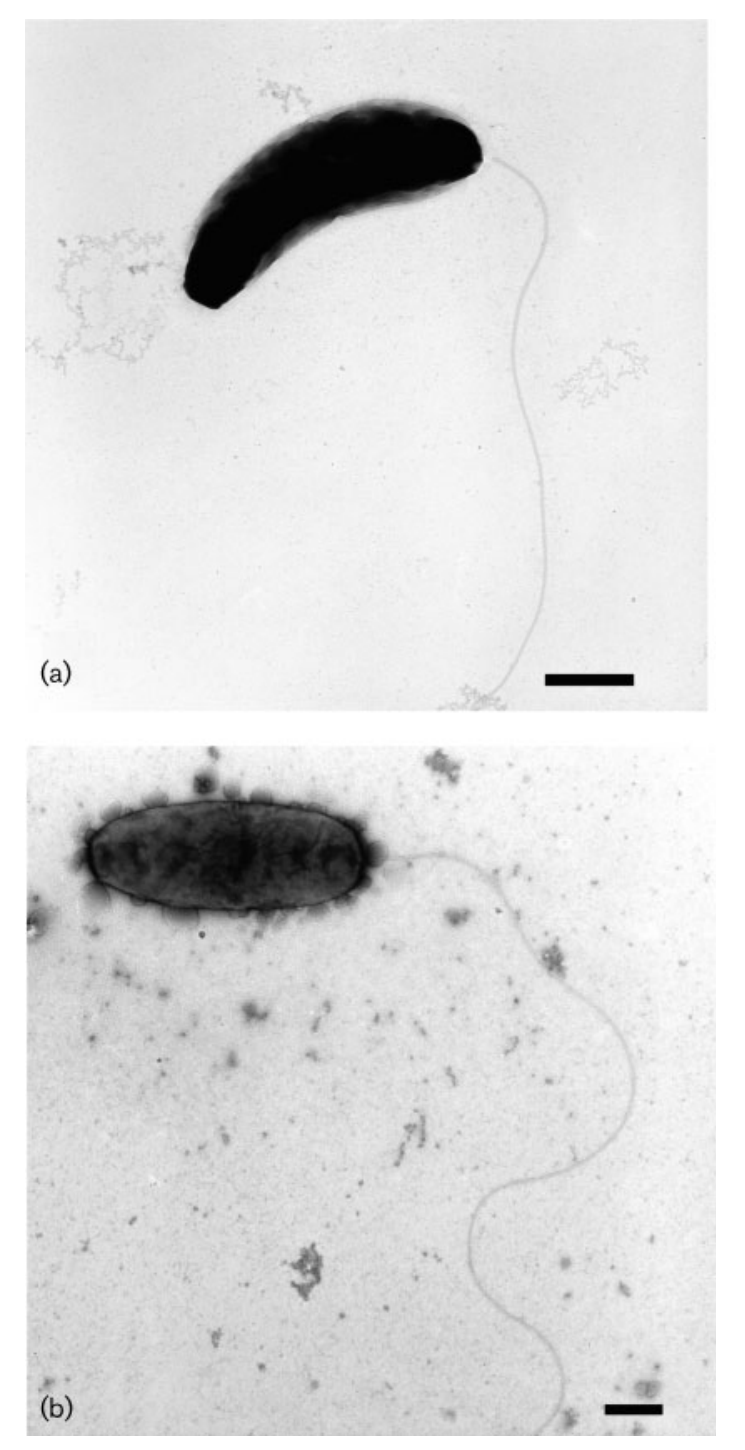

Fig. 1. Electron micrographs (negative stain with uranyl acetate) of Desulfovibrio ferrireducens sp. nov. $61^{\top}$ (a) and Desulfovibrio frigidus sp. nov. $18^{\top}(\mathrm{b})$, showing the sigmoid shape of strain $61^{\top}$ and the straight rod shape of strain $18^{\top}$. Cells of both strains are motile by a single monopolar flagellum. Bars, $0.5 \mu \mathrm{m}$.

several species of Desulfovibrio (Desulfovibrio desulfuricans, Desulfovibrio vulgaris, Desulfovibrio sulfodismutans, Desulfovibrio baarsii and Desulfovibrio sp. strain G-11) as well as for Desulfomicrobium baculatum and Desulfobacterium autotrophicum (Coleman et al., 1993; Lovley et al., 1993; Li et al., 2004). Growth by Fe(III) reduction has so far only been shown for the two sulfate-reducing bacteria Desulfobulbus propionicus and 'Desulfotomaculum reducens' (Tebo \& Obraztsova, 1998; Holmes et al., 2004).

Although isolated at different temperatures $(4,10$ and $17^{\circ} \mathrm{C}$ ), all three strains showed similar temperature optima for growth at $20-23^{\circ} \mathrm{C}$ (Table 1) and were able to grow at the freezing point of sea water, $-2^{\circ} \mathrm{C}$. According to their 
Table 1. Comparison of the characteristics of Desulfovibrio ferrireducens strain $61^{\top}$, Desulfovibrio frigidus strains $18^{\top}$ and 77 and closely related species

Strains/species: 1, Desulfovibrio ferrireducens sp. nov. $61^{\mathrm{T}} ; 2$, Desulfovibrio frigidus sp. nov. $18^{\mathrm{T}}$; 3, Desulfovibrio frigidus sp. nov. 77 ; 4, Desulfovibrio hydrothermalis; 5, Desulfovibrio zosterae; 6, Desulfovibrio salexigens. Data from Postgate \& Campbell (1966), Postgate (1984), Zellner et al. (1989), Nielsen et al. (1999) and Alazard et al. (2003). +, Substrate used for growth; -, substrate not used for growth; +/-, substrate reduced but no growth; $(+)$, substrate poorly utilized; ND, not determined. Electron acceptors tested but not reduced by strains $18^{\mathrm{T}}, 61^{\mathrm{T}}$ and 77 : nitrate $(20 \mathrm{mM})$, nitrite $(10 \mathrm{mM})$, oxygen (air), malate $(20 \mathrm{mM})$, fumarate $(20 \mathrm{mM})$ and manganese oxide (approx. $30 \mathrm{mM})$. Electron donors tested but not oxidized: acetate $(20 \mathrm{mM})$, butyrate $(10 \mathrm{mM})$, propionate $(10 \mathrm{mM})$, hexanoate $(3 \mathrm{mM})$, malate $(10 \mathrm{mM})$, butanol $(10 \mathrm{mM})$, pyruvate $(10 \mathrm{mM})$, fructose $\left(1 \mathrm{~g} \mathrm{l}^{-1}\right)$, glucose $\left(1 \mathrm{~g} \mathrm{l}^{-1}\right)$, glycerol $(10 \mathrm{mM})$, glycine $(10 \mathrm{mM})$, glutarate $(10 \mathrm{mM})$, serine $(10 \mathrm{mM})$, proline $(10 \mathrm{mM})$, betaine $(10 \mathrm{mM})$, sorbitol $(5 \mathrm{mM})$, nicotinate $(1 \mathrm{mM})$, yeast extract $\left(0 \cdot 05 \mathrm{~g} 1^{-1}\right)$, casein $\left(0 \cdot 05 \mathrm{~g} \mathrm{l}^{-1}\right)$ and choline chloride $(10 \mathrm{mM})$. Substrates tested for disproportionation but not used: lactate and fructose.

\begin{tabular}{|c|c|c|c|c|c|c|}
\hline Strain & 1 & 2 & 3 & 4 & 5 & 6 \\
\hline Temperature optimum $\left({ }^{\circ} \mathrm{C}\right)$ & 23 & $20-23$ & $21-22$ & 35 & $32 \cdot 5-34 \cdot 5$ & $34-37$ \\
\hline \multicolumn{7}{|l|}{ Electron acceptors: } \\
\hline Thiosulfate $(10 \mathrm{mM})$ & + & - & - & + & + & ND \\
\hline Sulfite $(2 \mathrm{mM})$ & + & + & + & + & + & ND \\
\hline Elemental sulfur & - & + & - & - & + & ND \\
\hline \multicolumn{7}{|l|}{ Electron donors: } \\
\hline Formate $(10 \mathrm{mM})$ & + & + & + & + & - & + \\
\hline Hydrogen $\left(\mathrm{H}_{2} / \mathrm{CO}_{2} ; 80: 20, \mathrm{v} / \mathrm{v}\right)$ & + & + & + & + & - & + \\
\hline Propanol (10 mM) & + & + & - & - & - & + \\
\hline Succinate $(10 \mathrm{mM})$ & + & - & - & - & - & + \\
\hline Glycerol (1 g $\left.{ }^{-1}\right)$ & - & - & - & + & ND & + \\
\hline Fructose $\left(1 \mathrm{~g} \mathrm{l}^{-1}\right)$ & - & - & - & - & + & ND \\
\hline \multicolumn{7}{|l|}{ Disproportionation: } \\
\hline Malate $(10 \mathrm{mM})$ & + & + & - & ND & - & - \\
\hline Pyruvate (10 mM) & + & - & + & + & + & - \\
\hline Fumarate $(10 \mathrm{mM})$ & + & + & - & $(+)$ & + & ND \\
\hline Glucose $\left(1 \mathrm{~g} \mathrm{l}^{-1}\right)$ & - & - & + & $\mathrm{ND}$ & - & ND \\
\hline Fructose $\left(1 \mathrm{~g} \mathrm{l}^{-1}\right)$ & - & - & - & - & + & ND \\
\hline DNA G $+\mathrm{C}$ content $(\mathrm{mol} \%)$ & $42 \cdot 0$ & $43 \cdot 3$ & ND & 47 & $42 \cdot 7$ & $45 \cdot 5$ \\
\hline
\end{tabular}

temperature range, the strains can be considered as psychrotolerant.

The DNA G + C contents were $42 \cdot 0$ and $43.3 \mathrm{~mol} \%$ for strains $61^{\mathrm{T}}$ and $18^{\mathrm{T}}$, respectively (Table 1 ), and were determined by the Deutsche Sammlung von Mikroorganismen und Zellkulturen (DSMZ), Braunschweig, Germany. Strains $18^{\mathrm{T}}$ and 77 were closely related to each other $(99 \cdot 9 \% 16 \mathrm{~S}$ rRNA gene sequence similarity) (Fig. 2), therefore we suggest that these two strains belong to the same species. 16S rRNA gene sequence similarity was $97.6 \%$ between strains $61^{\mathrm{T}}$ and $18^{\mathrm{T}}$ and $97 \cdot 5 \%$ between strains $61^{\mathrm{T}}$ and 77 (Fig. 2). DNA-DNA hybridization was done by the DSMZ and DNA-DNA relatedness was $14.5 \%$ between strains $61^{\mathrm{T}}$ and $18^{\mathrm{T}}$ and $18.3 \%$ between strains $61^{\mathrm{T}}$ and 77 . Therefore, we propose the description of two novel species: Desulfovibrio ferrireducens (type strain $61^{\mathrm{T}}$ ) and Desulfovibrio frigidus (type strain $18^{\mathrm{T}}$ ). Both strains $61^{\mathrm{T}}$ and $18^{\mathrm{T}}$ are closely related to the undescribed Desulfovibrio sp. strain Aspo3 (respectively $97 \cdot 4$ and $95 \cdot 4 \% 16 \mathrm{~S}$ rRNA gene sequence similarity) isolated from subterranean groundwater (Pedersen et al., 1996), as well as to Desulfovibrio hydrothermalis (95.7 and $95.0 \%)$ isolated from a deep-sea hydrothermal chimney (Alazard et al., 2003), Desulfovibrio zosterae (94.8 and $94 \cdot 3 \%$ ) isolated from marine seagrass roots (Nielsen et al., 1999 ) and Desulfovibrio salexigens ( $94 \cdot 6$ and $95 \%$ ) (Fig. 2).

The isolated strains and their closest relatives, Desulfovibrio hydrothermalis, Desulfovibrio zosterae and Desulfovibrio salexigens, share the ability to reduce sulfate and use lactate, ethanol, fumarate, formate plus acetate and hydrogen plus acetate as electron donors. They can be distinguished by their substrate usage and additionally by their temperature ranges of growth (Table 1). Desulfovibrio hydrothermalis, 


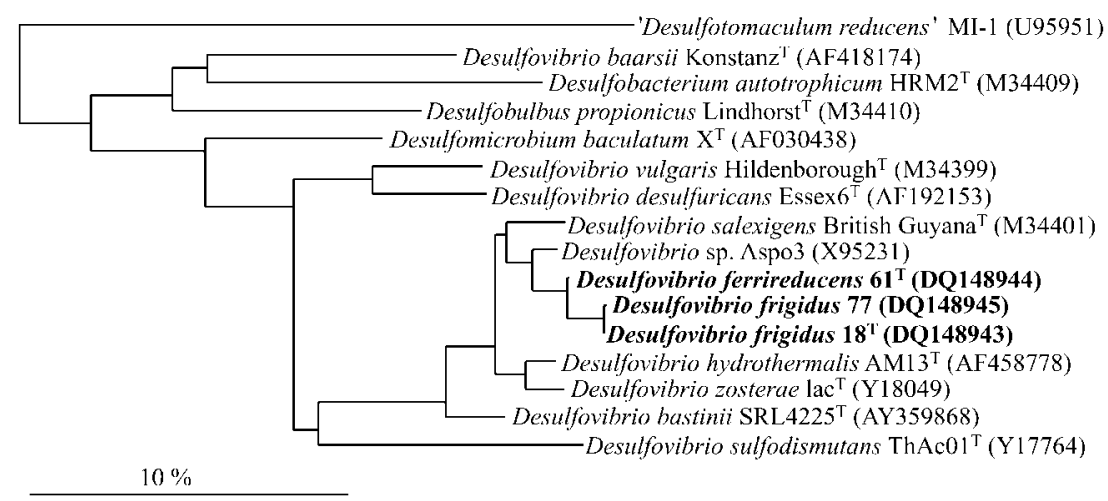

Fig. 2. Phylogenetic tree based on $16 \mathrm{~S}$ rRNA gene sequences showing the position of the isolated strains $18^{\top}, 61^{\top}$ and 77 within the genus Desulfovibrio and in relation to other sulfate-reducing bacteria with the ability to reduce $\mathrm{Fe}(\mathrm{III})$. The tree was calculated using maximum-likelihood algorithm with a $50 \%$ filter for Deltaproteobacteria. Bar, $10 \%$ estimated sequence divergence.
Desulfovibrio zosterae and Desulfovibrio salexigens are mesophiles with temperature optima at $33-37^{\circ} \mathrm{C}$ (Postgate, 1984; Nielsen et al., 1999; Alazard et al., 2003), whereas strains $18^{\mathrm{T}}$, $61^{\mathrm{T}}$ and 77 are psychrotolerant (temperature optima at $20-23^{\circ} \mathrm{C}$ ) and able to grow at $-2{ }^{\circ} \mathrm{C}$. As the three strains were isolated from fjord sediments with temperatures of $2-3{ }^{\circ} \mathrm{C}$ at the time of sampling, they are able to grow at the permanently low in situ temperature of Svalbard sediments.

\section{Description of Desulfovibrio ferrireducens sp. nov.}

Desulfovibrio ferrireducens [fer.ri.re.du'cens. L. n. ferrum iron; L. part. adj. reducens leading back, bringing back and in chemistry converting to a different oxidation state; N.L. part. adj. ferrireducens reducing $\mathrm{Fe}(\mathrm{III})$ to $\mathrm{Fe}(\mathrm{II})]$.

Cells are vibrioid or sigmoid, $2.5-5.5 \times 0.7 \mu \mathrm{m}$ in size, motile by a single polar flagellum. Gram-negative. No vitamins are required for growth. Lactate, formate, hydrogen, ethanol, propanol, fumarate and succinate are oxidized with sulfate reduction. Sulfate, thiosulfate and sulfite serve as electron acceptors. Iron compounds [Fe(III) oxide and $\mathrm{Fe}$ (III) citrate] are reduced without growth. Disproportionation of malate, pyruvate and fumarate. Optimum $\mathrm{NaCl}$ concentration is $1-2.5 \%$, and growth occurs between 0.7 and $4 \% \mathrm{NaCl}$; for $\mathrm{MgCl}_{2}$ the optimum concentration is between 0.02 and $2.5 \%$ and growth occurs up to a concentration of $3 \cdot 5 \%$. pH optimum is $7 \cdot 1-7 \cdot 5$ and $\mathrm{pH}$ range is $6 \cdot 3-7 \cdot 5$. Temperature optimum is $23^{\circ} \mathrm{C}$ and growth range is between -2 and $30^{\circ} \mathrm{C}$. The DNA G $+\mathrm{C}$ content is $42 \cdot 0 \mathrm{~mol} \%$.

The type strain, $61^{\mathrm{T}}\left(=\mathrm{DSM} 16995^{\mathrm{T}}=\mathrm{JCM} 12925^{\mathrm{T}}\right)$, was isolated from a permanently cold sediment of the west coast of Svalbard.

\section{Description of Desulfovibrio frigidus sp. nov.}

Desulfovibrio frigidus (fri'gi.dus. L. masc. adj. frigidus cold, referring to growth in the permanently cold sediment of Svalbard).

Cells are rod-shaped or vibrioid, $2-5 \times 0.7 \mu \mathrm{m}$ in size, motile by a single polar flagellum. Gram-negative. No vitamins are required for growth. Lactate, formate, hydrogen, ethanol, fumarate and alanine are oxidized with sulfate reduction; one strain oxidizes propanol. Sulfate and sulfite serve as electron acceptors; one strain reduces elemental sulfur. Iron compounds [Fe(III) oxide and Fe(III) citrate] are reduced without growth. Disproportionation of malate, pyruvate, fumarate and glucose is possible for one or the other strain. Growth range for $\mathrm{NaCl}$ and $\mathrm{MgCl}_{2}$ is different for the two strains, but the optimum $\mathrm{NaCl}$ concentration is $2-3 \%$, and growth occurs at $2-3 \cdot 5 \% \mathrm{NaCl}$; for $\mathrm{MgCl}_{2}$ the optimum concentration is around $0.4 \%$ and growth occurs up to a concentration of $1.9 \%$. $\mathrm{pH}$ optimum is $7 \cdot 1$ and $\mathrm{pH}$ range is $6 \cdot 9-7 \cdot 5$. Temperature optimum is at $20-23^{\circ} \mathrm{C}$ and growth range is from -2 to $25^{\circ} \mathrm{C}$. The DNA G $+\mathrm{C}$ content is $43 \cdot 3 \mathrm{~mol} \%$.

Strain $18^{\mathrm{T}}\left(=\mathrm{DSM} 17176^{\mathrm{T}}=\mathrm{JCM} 12924^{\mathrm{T}}\right)$ is the type strain. Strain 77 is a second strain of the species. Both strains were isolated from a permanently cold sediment at the west coast of Svalbard.

\section{Acknowledgements}

We thank Anke Toltz at the University of Bremen for help with the electron micrographs. Thanks to Carol Arnosti, Volker Brüchert, Niko Finke, Swantje Lilienthal and Christoph Vogt for the enjoyable trip to Svalbard and Stig Henningsen (Captain) and John Mortensen (first mate) for the interesting cruise with MS Farm. We thank the AlfredWegener-Institute for providing laboratory space at the Koldewey Station. This project was supported by the Max Planck Society.

\section{References}

Alazard, D., Dukan, S., Urios, A., Verhé, F., Bouabida, N., Morel, F., Thomas, P., Garcia, J.-L. \& Ollivier, B. (2003). Desulfovibrio hydrothermalis sp. nov., a novel sulfate-reducing bacterium isolated from hydrothermal vents. Int J Syst Evol Microbiol 53, 173-178.

Buchholz-Cleven, B. E. E., Rattunde, B. \& Straub, K. L. (1997). Screening for genetic diversity of isolates of anaerobic $\mathrm{Fe}$ (II)oxidizing bacteria using DGGE and whole-cell hybridization. Syst Appl Microbiol 20, 301-309.

Canfield, D. E., Jørgensen, B. B., Fossing, H. \& 7 other authors (1993). Pathways of organic carbon oxidation in three continental margin sediments. Mar Geol 113, 27-40.

Coleman, M. L., Hedrick, D. B., Lovley, D. R., White, D. C. \& Pye, K. (1993). Reduction of $\mathrm{Fe}(\mathrm{III})$ in sediments by sulphate-reducing bacteria. Nature 361, 436-438. 
Glud, R. N., Risgaard-Petersen, N., Thamdrup, B., Fossing, H. \& Rysgaard, S. (2000). Benthic carbon mineralization in a high-Arctic sound (Young Sound, NE-Greenland). Mar Ecol Prog Ser 206, 59-71.

Holmes, D. E., Bond, D. R. \& Lovley, D. R. (2004). Electron transfer by Desulfobulbus propionicus to Fe(III) and graphite electrodes. Appl Environ Microbiol 70, 1234-1237.

Jergensen, B. B. (1982). Mineralization of organic matter in the sea bed - the role of sulphate reduction. Nature 296, 643-645.

Kostka, J. E., Thamdrup, B., Glud, R. N. \& Canfield, D. E. (1999). Rates and pathways of carbon oxidation in permanently cold Arctic sediments. Mar Ecol Prog Ser 180, 7-21.

Li, Y.-L., Vali, H., Sears, S. K., Yang, J., Deng, B. \& Zhang, C. L. (2004). Iron reduction and alteration of nontronite NAu-2 by a sulfate-reducing bacterium. Geochim Cosmochim Acta 68, 3251-3260.

Lovley, D. R., Roden, E. E., Phillips, E. J. P. \& Woodward, J. C. (1993). Enzymatic iron and uranium reduction by sulfate-reducing bacteria. Mar Geol 113, 41-53.

Ludwig, W., Strunk, O., Westram, R. \& 29 other authors (2004). ARB: a software environment for sequence data. Nucleic Acids Res 32, 1363-1371.

Nielsen, J. L., Liesack, W. \& Finster, K. (1999). Desulfovibrio zosterae sp. nov., a new sulfate reducer isolated from surface-sterilized roots of the seagrass Zostera marina. Int J Syst Bacteriol 49, 859-865.

Pedersen, K., Arlinger, J., Ekendahl, S. \& Hallbeck, L. (1996). 16S rRNA gene diversity of attached and unattached bacteria in boreholes along the access tunnel to the Äspö hard rock laboratory, Sweden. FEMS Microbiol Ecol 19, 249-262.
Postgate, J. R. (1984). Genus Desulfovibrio Kluyver and van Niel 1936, 397 ${ }^{\mathrm{AL}}$. In Bergey's Manual of Systematic Bacteriology, vol. 1, pp. 666-672. Edited by N. R. Krieg \& J. G. Holt. Baltimore: Williams \& Wilkins.

Postgate, J. R. \& Campbell, L. L. (1966). Classification of Desulfovibrio species, the nonsporulating sulfate-reducing bacteria. Bacteriol Rev 30, 732-738.

Rysgaard, S., Thamdrup, B., Risgaard-Petersen, N., Fossing, H., Berg, P., Christensen, P. B. \& Dalsgaard, T. (1998). Seasonal carbon and nutrient mineralization in a high-Arctic coastal marine sediment, Young Sound, Northeast Greenland. Mar Ecol Prog Ser 175, 261-276.

Sagemann, J., Jørgensen, B. B. \& Greef, O. (1998). Temperature dependence and rates of sulfate reduction in cold sediments of Svalbard, Arctic Ocean. Geomicrobiol J 15, 85-100.

Tebo, B. M. \& Obraztsova, A. Y. (1998). Sulfate-reducing bacterium grows with $\mathrm{Cr}(\mathrm{VI}), \mathrm{U}(\mathrm{VI}), \mathrm{Mn}(\mathrm{IV})$, and $\mathrm{Fe}(\mathrm{III})$ as electron acceptors. FEMS Microbiol Lett 162, 193-198.

Thamdrup, B. \& Canfield, D. E. (1996). Pathways of carbon oxidation in continental margin sediments off central Chile. Limnol Oceanogr 41, 1629-1650.

Widdel, F. \& Bak, F. (1992). Gram-negative mesophilic sulfatereducing bacteria. In The Prokaryotes, pp. 3352-3378. Edited by A. Balows, H. G. Trüper, M. Dworkin, W. Harder \& K. H. Schleifer. New York: Springer.

Zellner, G., Messner, P., Kneifel, H. \& Winter, J. (1989). Desulfovibrio simplex spec. nov., a new sulfate-reducing bacterium from a sour whey digester. Arch Microbiol 152, 329-334. 